\title{
Attitude towards Learning of Science and Academic Achievement in Science among Students at the Secondary Level
}

\author{
U. Narmadha \\ Research Scholar, N.K.T. National College of Education for Women, Chennai-600 005 \\ Dr. S. Chamundeswari \\ Associate Professor, N.K.T. National College of Education for Women, Chennai-600 005
}

Accepted: May 21, 2013 Published: June 25, 2013

Doi:10.5296/jsr.v4i2.3910 URL: http://dx.doi.org/10.5296/jsr.v4i2.3910

\begin{abstract}
The present study aimed to investigate attitude towards learning of Science and academic achievement in Science among students at the secondary level. Using random sampling technique 422 students, from the secondary level in different systems of education, namely, state, matriculation and central board schools were chosen. The Attitude toward Learning of Science Scale (Grewal, 1972) was used to assess the attitude towards learning Science and the marks scored in Science were taken from their half yearly performance. The data collected was subjected to statistical analysis, namely, mean, standard deviation, ' $t$ ' - test, ' $F$ 'ratio, Karl Pearson's Product Moment Correlation Co-efficient 'r'. Results showed that the students belonging to the central board schools have a higher level of attitude towards learning of Science compared to students in state board but did not differ with students in matriculation board schools at the secondary level. Similarly, students belonging to central board schools performed better in Science subject compared to the students in state and matriculation board schools at the secondary level. The girls are significantly better in their attitude toward learning of Science when compared to the boys in all categories of schools. In matriculation and central board schools the girls are better than boys in their academic achievement in Science whereas in state board schools there is no significant difference in their gender. A positive correlation was found to exist between attitude towards learning Science and academic achievement in Science among the students.
\end{abstract}

Keywords: Attitude, Learning of Science, Academic Achievement

\section{INTRODUCTION}

Scientific progress is faster today than ever before. This progress is reflected not only by the 
many discoveries made each year but also by the thousands of scientists involved in research and by the vast sums of money spent on scientific work. As the number of scientists has grown, cooperation and communication among them have become increasingly important. Many recent achievements have resulted from scientists working in research teams. Hundreds of scientific journals, professional societies, and computerized information systems make it possible for scientists throughout the world to exchange information quickly and easily. Increasingly powerful and advanced equipment is helping scientists in many different fields expand knowledge about the world.

Nowadays, learning of Science becomes very important and learning Science in a more interactive way through the usage of communication technology is highly encouraged. Moreover, learning Science is also very beneficial as it has been linked with other subjects such as History, Geography, Mathematics, English and other languages. This will certainly help the children in many ways as they get to learn many things at a time.

Teachers should try to make learning of Science an enjoyable experience, the one that the children will remember for a life time as Science is an on-going process and it will continue even when these children have stepped out of primary school. Therefore, it is definitely a wise move to help these children to understand the importance of Science and the significance of learning Science. Under such circumstances, it becomes important to investigate the learning of Science by children, who are the potent citizens of tomorrow.

An early notable contribution towards Science was made by Klopfer (1971), who categorized a set of affective behaviours in Science education as:

* the manifestation of favourable attitudes towards Science and scientists;

* the acceptance of scientific enquiry as a way of thought;

* the adoption of 'scientific attitudes';

* the enjoyment of Science learning experiences;

* the development of interests in Science and Science-related activities; and

* the development of an interest in pursuing a career in Science or Science related work.

It is therefore in the interests of society, and the responsibility of educators, to improve students' attitude towards Science, and to prepare students to live in a highly scientific and technological society. The future of our society will be determined by citizens who are able to understand and help shape the complex influences of Science and technology on our world (Ungar, 2010).

A weak negative attitude towards learning Science was noticed among the students in Qatar, a matter that was reflected on their achievement in national tests. To test if the use of Problem Based Learning would improve the students' attitudes towards learning Science, Faris (2008) took a sample of 25 nine graders from Hamza school who were motivated to plan their own investigations and to implement their projects on the following two problems: (i) One World, One Environment; and (ii) Obesity Survey Study. The main objectives of the study were: (i) To test if the use of Problem Based Learning would improve the students' attitudes towards learning Science among nine graders in Hamza school; (ii) To provide high quality learning and better performance by allowing students to do some "real" Science through developing and testing their own hypothesis; (iii) To improve teamwork skills; (iv) To boost the students' 
confidence in their ability to apply knowledge and skills to problem-solving; (v) To enhance the presentation skills of the students; and (vi) To encourage the students to use ICT effectively. A questionnaire was developed to measure the students' attitudes. The analysis of the results and reviewing the reflective journal showed that 22 students out of 25 students, who participated in the project, had strong positive attitudes towards learning Science, working in groups and participating in project based learning. They also performed better in Science when compared to 3 students who could not yet determine their educational needs. This study is similar to the findings of an earlier study conducted by Tandogan and Orhan (2007).

Faris (2009) aimed to investigate the impact of homogeneous versus heterogeneous collaborative learning grouping in multicultural classes on the students' achievements and attitudes toward learning Science. Heterogeneity was unpacked through two dimensions: the cultural background, represented by the different nationalities present in the class and the students' different abilities. The interaction between these two factors and their combined effect on the achievement and attitudes were also investigated. The study also considered an approach to provide quality teaching for a diverse group of students by neutralizing the heterogeneity factor or reducing its negative effect. For this purpose, 100 nine graders from more than 10 countries in an independent preparatory school in Doha / Qatar were divided into four classes and distributed over the following learning "STAD" groups: (1) Heterogeneous by ability but homogeneous by nationality; (2) Heterogeneous by nationality but homogeneous by ability; (3) Entirely heterogeneous (i.e. by both the ability and the nationality); and (4) Entirely homogeneous (i.e. by both the ability and the nationality). A diagnostic placement test, standardized pretest and posttest in addition to the regular school tests were used to measure the achievement of the students. A Questionnaire was developed to measure the attitudes of the students towards learning Science as well as towards group working. The study concluded that the main effects of group structure on the students' attitudes towards learning Science were demonstrated by the heterogeneous group. It affected all the attitude components except the "working with students from different cultural backgrounds" dimension, where nearly all group types had the same effect. However, this positive attitude was enhanced when the effect of mixed ability classes was combined with the effect of multiculturalism. Having foreign students or students from different cultures in a mixed ability class, yielded the best desired results. Therefore, the researcher highly recommends maximizing the heterogeneity in a class in all possible ways. The implemented collaborative learning strategy made learning more fun and beneficial for the students enhanced their self confidence, academic awareness, and consequently their overall attitude towards Science. The heterogeneity factor had a negative effect on the achievement of the students. The students in the mixed ability classes scored less than the students in other groups. However, when the "same ability" groups contained students from different cultural backgrounds, the results were the most favourable. The optimum class composition that may yield best achievement results and constructs positive attitudes is a compromise that maximizes group diversity and prevents individual isolation. The interaction between the two factors (ability + multiculturalism) gives the best desired results. In multicultural classes, collaborative learning should be supported by a multicultural education program, otherwise it 
would have little if any positive effect on the students achievement and attitudes toward learning Science.

According to Oludipe and Oludipe (2010), Integrated Science plays vital role in Nigerian Science Education Programme, because it prepares pupils at the Junior Secondary School level for the study of core Science subjects at the Senior Secondary School level which in turn brings about students' interest in Science oriented courses at the tertiary institutions. Despite government's efforts to encourage Science teaching and learning among Nigerian students right from the Junior Secondary School level, the enrolment of students in core Science subjects and Science oriented courses at the Senior Secondary School level and tertiary institutions level respectively, is not encouraging. This is as a result of Junior Secondary School students' negative attitude towards integrated Science. Research reports indicate that this negative attitude was caused, majorly, by teachers' conventional (lecture) method of teaching integrated Science. Research reports on the effectiveness of constructivist-based teaching strategy revealed that the strategy enhanced students' academic performance. In view of this, this study examines the effectiveness of constructivist-based teaching strategy on academic performance in integrated Science by Junior Secondary School students in South-West Nigeria. Quasi-experimental research design was used to achieve the purpose of this study. Participants were 120 Junior Secondary School Students randomly selected from four out of the 25 co-educational Junior Secondary Schools in Ijebu-ode local Government area of Ogun State, South-west Nigeria. Findings revealed that the constructivist instructed students had higher scores on the post test and the delayed post test, compared to those exposed to conventional (lecture) method of teaching. The author concluded that if integrated Science teachers could incorporate constructivist-based teaching strategy into their teaching methods, there would be an improvement in academic performance of junior secondary school students in integrated Science. The researchers recommended that integrated Science teachers should incorporate constructivist-based teaching strategy in their methods of teaching.

Taking lower-secondary schooling within the English educational system as an example, Kenneth (2011) illustrates the contribution of two bodies of international scholarship to the scoping of research-based pedagogical development aimed at improving student attitude and achievement in Science and Mathematics. After sketching the English context of systemic reform, the paper uses findings from the Trends in International Mathematics and Science Study (TIMSS) series to illuminate changes in performance, analyzed within a framework of cross-system and between-subject comparison. Contrary to the optimistic picture from national assessment, the TIMSS findings suggest that systemic reform has produced fundamental gains only in student achievement in Mathematics, and serious decline in student attitude towards both Mathematics and Science. Prompted by more favorable patterns elsewhere, the paper then triangulates the findings of recent meta-analytic research syntheses to identify promising lines of pedagogical development. Despite important differences in the conceptual frameworks and analytic methods of these syntheses, reasonably robust conclusions can be drawn about the effectiveness of four teaching components: "domain-specific inquiry" for student achievement in both subjects, student attitude in Science, and learning processes in Mathematics; "cooperative group work" for learning and 
attitude in Science; "contextual orientation" for achievement in Science; and "active teaching" for achievement in Mathematics. Equally, discrepancies between findings or insufficiencies of evidence highlight a number of impacts particularly deserving deeper analysis or further investigation: "cooperative group work" on achievement outcomes, differing forms of "learning assessment" on both attitude and achievement outcomes, "contextual orientation" on outcomes in Mathematics, and "active teaching" on outcomes in Science.

A study was conducted by Ali and Awan (2013) to examine the relationship of attitude of secondary school students towards Science with the achievement in the subjects of Physics, Chemistry, Biology and Mathematics. TOSRA was used to measure students' attitude towards Science and data was collected from 1,885 students of 10th grade. Simple correlation (r), Multiple regression analyses $(\mathrm{R})$ and standardized regression coefficients $(\beta)$ were used to investigate the relationships between attitude towards Science and achievement in Science. The results of the study indicated that attitude towards Science had significantly positive relationship with the achievement of Science students at secondary level.

\section{NEED FOR THE STUDY}

One of the major causes for concern is the enduring 'swing away from Science' in many countries. Since only those students, who take Science, or Science and Mathematics, are able to pursue further in scientific education and scientific careers, the decline in the number of Science-based students as a proportion of all students eligible for higher education in the country has raised concerns about the nation's economic future (Dearing 1996; Roberts 2002). At the core of such concerns is recognition that the nation's standards of 'achievement and competitiveness, is based on a highly educated, well trained and adaptable workforce', and that the low uptake of Mathematics and Science and the negative attitudes towards these subjects poses a serious threat to economic prosperity.

\section{OBJECTIVES OF THE PRESENT STUDY}

(i) To investigate if there is any significant relationship between the select variables among students in state, matriculation and central board schools at the secondary level

(ii) To investigate if there is any significant difference in attitude toward learning of Science and academic achievement among students in state, matriculation and central board schools at the secondary level;

(iii) To investigate if there is any significant difference in attitude toward learning of Science and academic achievement among boys and girls in state matriculation and central board schools at the secondary level

\section{METHOD OF INVESTIGATION}

\subsection{Sample}


From the target population a sample of 422 students, were chosen from the secondary level studying in different systems of education, namely, state, matriculation and central board schools. The chosen sample comprised of 131students from the state board school, 157 students from matriculation school and 134 students from the central board school. Random sampling method was employed in the present research to collect, analyze and interpret the data. Data collected from the select sample was scored and subjected to statistical processing for verification of hypothesis.

\subsection{Tools Used}

Attitude toward Learning of Science Scale (Grewal, 1972) was chosen in the present study as it is a scale to assess attitudes of students done in the indigenous settings. It was also easy to administer and directions given were simple. The rating scale consists of 20 items relating to attitudes of students toward learning of Science possessed by students contributing the effective learning and performance in Science.

\subsection{Pilot Study}

A pilot study was conducted to establish the validity and reliability of the questionnaire used for the study. For the pilot study, a group of 30 students at the Secondary Level from different types of schools in the city of Chennai were selected by simple random sampling method. The reliability of the tool Attitude toward Learning of Science (Grewal, 1972) was established by using the split-half method. The reliability co-efficient for the two-halves was found to be 0.65 , significant at 0.01 level. The square root of the reliability is treated as validity of the test. Thus the validity was found to be 0.76 , significant at 0.01 level.

\section{ANALYSES AND INTERPRETATION OF DATA}

The data was analyzed and the results are presented in the following tables.

Table-1. Analysis of Correlation between the Select Variables of Students at the Secondary Level

\begin{tabular}{|l|l|l|}
\hline & $\begin{array}{l}\text { Attitude toward } \\
\text { Learning of Science }\end{array}$ & $\begin{array}{l}\text { Academic Achievement in } \\
\text { Science of Students }\end{array}$ \\
\hline $\begin{array}{l}\text { Attitude toward Learning } \\
\text { of Science }\end{array}$ & 1 & $0.39 * *$ \\
\hline $\begin{array}{l}\text { Academic Achievement in } \\
\text { Science of Students }\end{array}$ & $\mathrm{X}$ & 1 \\
\hline
\end{tabular}

**Significant at 0.01 level

From Table-1 it is evident that the select variables of the present study. Namely, attitude toward learning of Science and academic achievement in Science are positively correlated with each other and significant at 0.01 level.

Table-2. Analysis of Variance of Students in different Categories of Schools at the Secondary Level 


\begin{tabular}{|c|c|c|c|c|c|}
\hline Variable & $\begin{array}{ll}\text { Source } & \text { of } \\
\text { Variation }\end{array}$ & $d f$ & $\begin{array}{ll}\text { Sum } & \text { of } \\
\text { Squares }\end{array}$ & $\begin{array}{l}\text { Mean of Sum } \\
\text { of Squares }\end{array}$ & $F$-ratio \\
\hline \multirow{3}{*}{$\begin{array}{l}\text { Attitude } \\
\text { toward } \\
\text { Learning of } \\
\text { Science }\end{array}$} & Between groups & 2 & 111630.76 & 55815.38 & \multirow{3}{*}{$519.91 * *$} \\
\hline & Within groups & 419 & 44982.13 & 107.36 & \\
\hline & Total & 421 & 156612.89 & - & \\
\hline \multirow{3}{*}{$\begin{array}{l}\text { Academic } \\
\text { Achievement } \\
\text { in Science }\end{array}$} & Between groups & 2 & 10332.35 & 5166.18 & \multirow{3}{*}{$25.35 * *$} \\
\hline & Within groups & 419 & 85380.35 & 203.77 & \\
\hline & Total & 421 & 95712.70 & - & \\
\hline
\end{tabular}

** Significant at 0.01 level

In Table-2, for the analysis of variance, different categories of schools are treated as

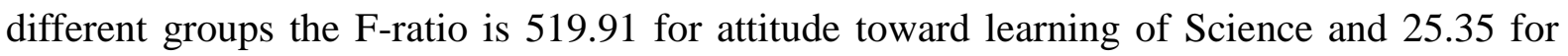
academic achievement in Science, which is significant at 0.01 level. Thus there is a significant difference in attitude toward learning of Science and academic achievement in Science among students in different categories of schools at the secondary level. In order to establish the actual degree of difference between the students belonging to different categories of schools namely, state, matriculation and central board schools, critical ratios were worked out and the actual difference between the mean scores were established are presented below in Table-3.

Table-3. Statistical Analysis of Means of Selected Variables of Students in different Categories of Schools at the Secondary Level

\begin{tabular}{|c|c|c|c|c|c|c|c|}
\hline Variable & Category & $\begin{array}{l}\text { Sample } \\
\text { Size }\end{array}$ & Mean & SD & SEM & SED & CR \\
\hline \multirow{6}{*}{$\begin{array}{l}\text { Attitude } \\
\text { toward } \\
\text { Learning of } \\
\text { Science }\end{array}$} & State Board & 131 & 25.95 & 4.74 & 0.41 & \multirow[b]{2}{*}{1.39} & \multirow[b]{2}{*}{$10.42 * *$} \\
\hline & $\begin{array}{l}\text { Matriculation } \\
\text { Board }\end{array}$ & 157 & 40.39 & 15.25 & 1.22 & & \\
\hline & State Board & 131 & 25.95 & 4.74 & 0.41 & \multirow{2}{*}{0.71} & \multirow{2}{*}{$57.17 * *$} \\
\hline & Central Board & 134 & 66.34 & 6.59 & 0.57 & & \\
\hline & $\begin{array}{l}\text { Matriculation } \\
\text { Board }\end{array}$ & 157 & 40.39 & 15.25 & 1.22 & \multirow[t]{2}{*}{1.42} & \multirow[t]{2}{*}{$18.29 * *$} \\
\hline & Central Board & 134 & 66.34 & 6.59 & 0.57 & & \\
\hline \multirow{3}{*}{$\begin{array}{l}\text { Academic } \\
\text { Achievement } \\
\text { in Science }\end{array}$} & State Board & 131 & 59.58 & 13.32 & 1.16 & \multirow[b]{2}{*}{1.67} & \multirow[b]{2}{*}{$3.33 * *$} \\
\hline & $\begin{array}{l}\text { Matriculation } \\
\text { Board }\end{array}$ & 157 & 65.15 & 14.76 & 1.18 & & \\
\hline & State Board & 131 & 59.58 & 13.32 & 1.16 & 1.72 & $7.25 * *$ \\
\hline
\end{tabular}




\begin{tabular}{|l|l|l|l|l|l|l|l|}
\hline & Central Board & 134 & 72.04 & 14.59 & 1.26 & & \\
\cline { 2 - 7 } & $\begin{array}{l}\text { Matriculation } \\
\text { Board }\end{array}$ & 157 & 65.15 & 14.76 & 1.18 & \multirow{2}{*}{1.73} & $3.99 * *$ \\
\cline { 2 - 6 } & Central Board & 134 & 72.04 & 14.59 & 1.26 & & \\
\hline
\end{tabular}

**Significant at 0.01 level

In Table-3, it is seen that the students in central board schools are significantly better in their attitude toward learning of Science and academic achievement in Science when compared to the students in matriculation and state board schools.

Table-4. Statistical Analysis of Means of Selected Variables of Boys and Girls in different Category of Schools at the Secondary Level

\begin{tabular}{|c|c|c|c|c|c|c|c|c|}
\hline Variable & Category & Gender & $\begin{array}{l}\text { Sample } \\
\text { Size }\end{array}$ & Mean & SD & SEM & SED & CR \\
\hline \multirow{6}{*}{$\begin{array}{l}\text { Attitude } \\
\text { toward } \\
\text { Learning of } \\
\text { Science }\end{array}$} & \multirow{2}{*}{ State Board } & Boys & 86 & 25.63 & 4.57 & 0.49 & \multirow{2}{*}{0.87} & \multirow{2}{*}{$1.06^{* *}$} \\
\hline & & Girls & 45 & 26.56 & 5.06 & 0.75 & & \\
\hline & \multirow{2}{*}{$\begin{array}{l}\text { Matriculation } \\
\text { Board }\end{array}$} & Boys & 68 & 23.76 & 5.18 & 0.63 & \multirow{2}{*}{0.72} & \multirow{2}{*}{$40.49 * *$} \\
\hline & & Girls & 89 & 53.09 & 3.89 & 0.41 & & \\
\hline & \multirow{2}{*}{$\begin{array}{l}\text { Central } \\
\text { Board }\end{array}$} & Boys & 53 & 63.04 & 6.23 & 0.84 & \multirow{2}{*}{1.07} & \multirow{2}{*}{$5.12 * *$} \\
\hline & & Girls & 81 & 68.51 & 5.98 & 0.67 & & \\
\hline \multirow{6}{*}{$\begin{array}{l}\text { Academic } \\
\text { Achievement } \\
\text { in Science }\end{array}$} & \multirow[t]{2}{*}{ State Board } & Boys & 86 & 58.15 & 14.18 & 1.53 & \multirow{2}{*}{2.43} & \multirow{2}{*}{$1.71^{\mathrm{NS}}$} \\
\hline & & Girls & 45 & 62.31 & 11.14 & 1.66 & & \\
\hline & \multirow{2}{*}{$\begin{array}{l}\text { Matriculation } \\
\text { Board }\end{array}$} & Boys & 68 & 60.56 & 12.56 & 1.52 & \multirow{2}{*}{2.30} & \multirow{2}{*}{$3.53 * *$} \\
\hline & & Girls & 89 & 68.65 & 15.40 & 1.63 & & \\
\hline & \multirow{2}{*}{$\begin{array}{l}\text { Central } \\
\text { Board }\end{array}$} & Boys & 53 & 63.98 & 16.74 & 2.30 & \multirow{2}{*}{2.32} & \multirow{2}{*}{$5.76^{* *}$} \\
\hline & & Girls & 81 & 77.31 & 10.04 & 1.12 & & \\
\hline
\end{tabular}

**Significant at 0.01 level

In the above Table-4, it is seen that the girls are significantly better in their attitude toward learning of Science when compared to the boys in all categories of schools. In matriculation and central board schools the girls are better than boys in their academic achievement in Science whereas in state board schools there is no difference in gender..

\section{DISCUSSION}

Several studies in Science education have investigated the relationship between student attitudes toward learning of Science and their academic achievement in Science (Rennie, and Punch, 1991; Cukrowska and others, 1999; Papanastasiou and Zembylas, 2004; Tuan and others, 2005). In general, these investigations have found conflicting correlations between attitude and achievement in Science. Cukrowska and others (1999) reported a positive relationship between attitudes and academic achievement in first-year Chemistry (Cukrowska and others, 1999). . Based on their study of junior high school students Tuan and others (2005) reported a positive correlation between achievements and both attitude and motivation toward learning Science However, Rennie and Punch (1991) reported a borderline significant correlation between subsequent achievement and student attitudes toward Science in 8th 
grade students.

In the present study, it was found that students in central board schools have significantly greater interest in Science when compared to their counter parts in matriculation and state board schools. The syllabus of central board schools is very interesting and application oriented and this enables teachers to plan for more application oriented assignments and projects during their classroom activities. Learning of Science for these students is more effective, because of the interest developed in the subject. Thus these students at the secondary level in central board schools are able to perform significantly better when compared to the secondary level students in the other two categories of schools namely matriculation and state board. It is also found that the girls are better than boys in both attitude towards learning of Science and academic achievement in Science in all three categories of schools following different systems of education. These results are contradictory to the early researches conducted by Schibeci's (1984), Becker (1989) and Weinburgh (1995).

\section{EDUCATIONAL IMPLICATIONS AND RECOMMENDATIONS}

Each country has its own challenges for Science education. The challenges for learners are identified based on the evidence collected by international or domestic surveys. To overcome these challenges, new school curriculum is planned and implemented. School-based lesson study contributes to the realization of the intended curriculum as the implemented one. It is important that students today understand that Science is more than what they read in a text book. As educators, parents and mentors it is our responsibility to take Science beyond the pages of a book. By developing creative and innovative lesson plans that demonstrate the cause and effect of Science, we have the opportunity to bring Science to life for our children.

Academic achievement in Science has been in focus for those who are interested in dealing with the practical problems of under development in order to bring about greater work efficiency and institution building. The need for achievement in Science has been greatly felt in every field because it is the main key for academic growth. Academic achievement in Science tries to seek some standard of excellence and may be shown either in competing with others, surfing one's own level of performance, unique accomplishment or an involvement in all possible walks of life. There is a great need for the development and achievement of Science. All the accomplishments are based on it and it has a direct bearing on the occupational choice and the success of the students laying more trust in their own ability and effort.

Every school should organize Science fairs at least once a year and this should include the exhibits of the students as well as demonstration talks by experts, film shows on scientific topics ,debates and declamation magic. Schools, scientific plays, etc. Teacher and the pupils should collaborate towards the success of the fair, it should be mainly an activity of the scientific work in practical; it can make an appeal to visitors which the academic type of activities may fail to provide.

\section{CONCLUSION}


For schools to be effective and make a difference in student learning, they must hold teaching and learning at the center of their work. Additionally, realizing teachers have a significant impact on student learning, teachers should strive to ensure that students are at the center of learning and that classroom instruction provides rich and meaningful curriculum for the full range of students in schools.

In practice, Science as a process involves an integration of knowledge, skills, and attitudes to develop scientific understanding. Practical work in Science can include experiencing phenomena, developing practical skills or techniques, and carrying out investigations. Investigations provide key opportunities for students to extend their understanding in Science. They also enable students to develop the scientific skills and attitudes required to enhance their ability to explore phenomena and events and to solve problems. It can be expected that, as they learn, students will show an increasing sophistication in the skills they use in their investigations.

To conclude, the present study has shown that there is a relationship between attitude toward learning of Science and academic achievement in Science of secondary school students. The present study also revealed that gender, type of school, the management and the medium of instruction has significant bearing of achievement in Science and attitude to learning of Science of secondary school. The boys and girls among the secondary school section studying in the different types of school have a definite influence on the attitude towards Science. Thus it could be concluded that a positive attitude towards learning of Science would enhance the achievement in Science. Keeping in mind the importance of learning Science, it becomes very important for schools and families in particular and society at large to foster good attitude toward learning, intelligence, learning skills among students and provide good socio-economic conditions for their effective learning and performance in Science.

\section{REFERENCES}

Ali, M.S and Awan, A.S (2013) Attitude towards Science and its Relationship with Students' Achievement in Science. Interdisciplinary Journal of Contemporary Research in Business 4(10).

Anastasi, A. (1990). Psychological Testing, New York: Macmillan Publishing Co.

Becker, B.J. (1989). Gender and Science Achievement: A Reanalysis of Studies from two Meta-Analyses. Journal of Research in Science Teaching, 26,141-169

Cukrowska, E., Staskun, M.G. and Schoeman, H.S. (1999). South African Journal of Chemistry, 52, 8-15.

Dearing, R. (1996). Review of Qualifications for 16-19 Year Olds. Hayes, Middlx: SCAA Publications.

Faris, A. (2008).The Impact of PBL on the Students' Attitudes towards Science among Nine Graders in Hamza Independent School. Retrieved from ERIC database. (ED502097) Faris, A.O. (2009). The Impact of Homogeneous vs. Heterogeneous Collaborative Learning Groups in Multicultural Classes on the Achievement and Attitudes of Nine Graders towards Learning Science. Online submission, (ED504109). 


\section{I Macrothink}

Journal of Sociological Research

ISSN 1948-5468

2013, Vol. 4, No.2

George, R. (2006). A Cross-domain Analysis of change in Students' Attitudes toward Science and Attitudes about the utility of Science. International Journal of Science Education, 28,571-589.

Grewal, A. (1972). Science Attitude Scale, National Psychological Corporation, Agra.

Kenneth, R.(2011) Using International Study Series and Meta-Analytic Research Syntheses to Scope Pedagogical Development Aimed at Improving Student Attitude and Achievement in School Mathematics and Science. International Journal of Science and Mathematics Education, 9(2),419-458.

Klopfer, L. (1971). "Evaluation of Learning in Science". In B. Bloom, J. Hastings, and G. Madaus (Eds.), Handbook of Summative and Formative Evaluation of Student Learning. New York: McGraw-Hill, 559-641.

Neathery, M.F. (1997). Elementary and Secondary Students ${ }^{e e}$ Perceptions Toward Science and Correlation with Gender, Ethnicity, Ability, Grade, and Science Achievement. Electronic Journal of Science Education, 2(1).

Oludipe, B. and Oludipe, D. (2010). Effect of Constructivist-Based Teaching Strategy on Academic Performance of Students in Integrated Science at the Junior Secondary School Level Educational Research and Reviews, 5(7),347-353.

Osborne, J., Simon, S., and Collins, S. (2003). Attitudes towards Science: a review of the literature and its implications. International Journal of Science Education, 25, 1049-1079.

Papanastasiou, E.C., and Zembylas, M. (2004). The Effect of Attitudes on Science Achievement: A Study Conducted among High School Pupils in Cyprus. International Review of Education, 48(6), 469-484.

Rennie, L.J., and Punch, k.E. (1991). The Relationship between affect and Achievement in Science. Journal of Research in Science Teaching, 28, 93-209.

Roberts, G, (2002) SET for Success: The Supply of People with Science, Technology, Engineering and Mathematics, Skills, HM Treasury, London

Schibeci, R.A. (1984). Attitudes to Science: An Update. Studies in Science Education, 11(1) 26-59

Tandogan, R.O. and Orhan, A. (2007). The Effects of Problem-Based Active Learning in Science Education on Students' Academic Achievement, Attitude and Concept Learning Eurasia. Journal of Mathematics, Science and Technology Education 3(1), 71-81.

Ungar, S.J. 2010. "Seven Major Misperceptions about the Liberal Arts." The Chronicle of Higher Education.

Weinburgh, M. (1995). Gender Differences in Student Attitudes toward Science: A Meta-Analysis of Literature From 1970 To 1991. Journal of Research in Science Teaching, 32(4), 387-398. 